\title{
Biochemical Performance of Rice (Oryza sativa) Genotypes under Submergence Stress in Odisha, India
}

\author{
Soumya Mishra ${ }^{1}$, Manoranjan Kar ${ }^{1}$, S.P. Monalisa ${ }^{2 *}$ and Alaka Sahu ${ }^{1}$ \\ ${ }^{1}$ Department of Plant Physiology, ${ }^{2}$ Department of Seed Science and Technology, \\ OUAT, Bhubaneswar, Odisha, India \\ *Corresponding author
}

A B S T R A C T

\begin{tabular}{|l|}
\hline Ke y w or d s \\
Rice, Submergence, \\
Genotypes, \\
Carbohydrates, \\
Antioxidants. \\
\hline Article Info \\
\hline Accepted: \\
04 September 2017 \\
Available Online: \\
10 October 2017 \\
\hline
\end{tabular}

Submergence or flood is one of the major harmful abiotic stresses in the low-lying countries and crop losses due to water logging are considerably high. A total of 22 million hectares of rice-growing area is adversely affected by flash flooding, half of which is in eastern India. The present experiment was conducted in Adaptive Research Station, Sakhigopal, Puri to screen out the rice genotypes for submergence adaptation traits under agro-climatic ecosystem of Odisha. The present study indicated that among the selected genotypes "Varsadhan" contributed highest yield.

\section{Introduction}

Rice (Oryza sativa) is the staple food for more than $50 \%$ the global population, is a semi aquatic plant, particularly able to survive under the conditions of prolonged oxygen deprivation, at both seedling and adult stages. The submergence-tolerant rice genotype is expected to help rice farmers in Asian countries, where $90 \%$ of the world's rice production and consumption takes place. By using the submergence-tolerant rice genotype, the survival rate of rice plants under completely submerged condition is increased. However, the physiology and biochemistry from the use of tolerance genotypes remain applicable limitations in the field. In order to identify the traits required to improve genetic adaptability of rice plants to submergence conditions, it is necessary to properly characterize the floodwater environment and to closely investigate the physiological processes behind the plants. Complete submergence hastens degradation of chlorophyll content in susceptible rice genotypes compared to tolerant ones (Ella et al., 2003; Panda et al., 2006). Uncertainty of rainfall coupled with water logging or submergence stress is a major factor affecting the rice yield in India and as well as in Odisha which is one of the important constraints in India, particularly in the eastern Indian states (Sarkar et al., 2006, 2009).

Agriculture in Odisha in a way is synonymous to rice cultivation. In Odisha, rice is grown in 
an area of 44 lakh hectares with an average productivity of $2.3 \mathrm{MT} / \mathrm{ha}$ which is much less in comparison to national average of 104.3 MT ha ${ }^{-1}$. The vagaries of monsoon play havoc in cropping seasons affecting the yield negatively. Rice plants that exhibit only limited elongation during submergence often show tolerance to complete flooding. Much of the injury to plants caused by abiotic stresses is associated with oxidative damage at cellular level. Damage to membrane integrity is a common effect of stress, especially in the case of low oxygen. Under anoxia, a decrease in membrane integrity is a symptom of injury, measured as changes in lipid content and composition, and also activation of lipid peroxidation (Blokhina et al., 2003). Plants have active oxygen-scavenging systems consisting of several antioxidant enzymes, and some low molecules of non-enzyme antioxidants, which can neutralize the free radicals and thus retard the progress of many injuries associated with oxidative stress and reactive oxygen species (ROS). ROS are common components of biochemical changes in the chloroplasts, mitochondria or in peroxisomes, when plants are subjected to harmful stress conditions. Among all the antioxidant enzymes, superoxide dismutase (SOD plays key roles in ROS detoxification in cells. With this backdrop, the current study was conducted in Adaptive Research Station, Sakhigopal, Puri during Kharif 2015 to screen out the rice genotypes for submergence adaptation traits under agro-climatic ecosystem of Odisha.

\section{Materials and Methods}

Seven rice genotypes (180 days duration) namely Varsadhan, Hanseswari, Sarala, Jaladhan-1, Jaladhan-2, Champa and Bankoi were employed in the study. The seeds of these varieties were line sown in separate seed beds in wet season (at the middle of July) for seedling development. The main plot was divided into three replications. The experimental design adopted for this research work was simple randomized block design (RBD).

\section{Biochemical estimations}

\section{Estimation of chlorophyll content}

The leaf samples were immediately kept in moist polythene bags to keep them turgid. 100 grams of fresh leaf was taken from the middle portion of the leaf and were cut into small pieces. The leaf discs were then put in $80 \%$ $\mathrm{v} / \mathrm{v}$ acetone solution and kept in dark for 24 hours. Then they were filtered by Whatman No.1 filter paper and the filtrate was used to record the absorbance (OD) at $645 \mathrm{~nm}$ and $663 \mathrm{~nm}$. The respective chlorophyll content was calculated using the following formula and expressed as $\mathrm{mg} \mathrm{g}^{-1} \mathrm{FW}$ leaf.

Chlorophyll-a $=(12.7 \times$ OD663 $-2.69 \times$ OD645) x V/1000 x $\mathrm{W}_{\mathrm{f}}$

Chlorophyll-b $=(22.9 \times$ OD645 $-4.68 \times$ OD663) x V/1000 x W

Total Chlorophyll $=(20.2 \times$ OD645 $-8.02 \times$ OD663) x V/1000 x $\mathrm{W}_{\mathrm{f}}$

Where, OD645 = OD value at $645 \mathrm{~nm}$, OD663 = OD value at $663 \mathrm{~nm}, \mathrm{~V}=$ Total volume of extract $(\mathrm{ml}), \mathrm{W}_{\mathrm{f}}=$ Fresh weight of leaf $(\mathrm{g})$

\section{Estimation of peroxidase activity}

200 mg plant sample was taken and homogenized with $10 \mathrm{ml}$ of Phosphate buffer $0.1 \mathrm{M}$ ( $\mathrm{pH}$ 6.0). It was centrifuged at 10,000 rpm at $4 \mathrm{C}$ for 30 minutes. The supernatant collected and stored at low temperature. The supernatant was used for enzyme assay and estimated the enzyme activity as given below. Shake the mixture well and keep it at $37^{\circ} \mathrm{C}$ on water bath for 10 minutes for the formation of purpurogallin. Measure the 
activity at $430 \mathrm{~nm}$ and express result as enzyme unit per gram fresh weight or per gram protein basis.

\section{Estimation of Superoxide Dismutase (SOD) activity}

Superoxide dismutase (SOD) is assayed on the basis of its ability of inhibit the photochemical reduction of nitro blue tetrazolium (NBT) into blue formazon which has a wavelength maximum at $560 \mathrm{~nm}$. SOD essentially inhibited the formation of the blue formazon and could be quantified on this basis. About $0.2 \mathrm{~g}$ FW leaf sample was weighted (cut into small pieces).

Addition of pinch of acid-washed sand and 2 $\mathrm{ml}$ cold phosphate buffer $\mathrm{pH} 7.0$ was done, $(0.05 \mathrm{M})$ Grind in clean, dry mortar and pestle in ice bath. It was transfer to centrifuge tubes and wash $3 \mathrm{x}$ with buffer $(1 \mathrm{ml}$ each of the buffer $\mathrm{pH} 7.0$ and $\mathrm{pH} 7.8$ which were used in initial trial extraction a total of $2 \mathrm{ml}$ per washing) to make a total of $8 \mathrm{ml}$. It was Centrifuged at $30,000 \times \mathrm{g}$ for 30 minutes at 0 $4^{\circ} \mathrm{C}$ (about 15,000 rpm in our refrigerated centrifuge, be sure to put tubes of more or less the same weight in exactly opposite positions to balance). The clear soup was collected and kept at $0-4^{\circ} \mathrm{C}$ for assay.

\section{Proline Content}

Fresh leaves $(0.5 \mathrm{~g})$ were ground in mortar and pestle with $10 \mathrm{ml}$ of $3 \%$ sulpho-salicyclic acid and the homogenate was centrifuged at $18000 \mathrm{rpm}$. The homogenate was filtered. Two $\mathrm{ml}$ of filtrate was added to two $\mathrm{ml}$ of glacial acetic acid and $2 \mathrm{ml}$ of acid ninhydrin and test tubes were kept for $1 \mathrm{~h}$ at $100^{\circ} \mathrm{C}$ in water bath, followed by ice bath. The reaction mixture was vortexed with $4 \mathrm{ml}$ of toluene. Toluene layer was separated and absorbance was read at $520 \mathrm{~nm}$. A standard curve of proline was used for calibration and expressed as $\mathrm{mg} \mathrm{g}^{-1} \mathrm{FW}$.

\section{Carbohydrate estimation}

$100 \mathrm{mg}$ of powdered dry sample was taken into in powder form and extracted using $80 \%$ ethanol (v/v). The exert was then used for sugar analysis by adding anthrone reagent, followed by measurement of absorbance at $630 \mathrm{~nm}$ using a spectrophotometer. In case of simple carbohydrate estimation the sample was kept in a boiling tube and hydrolyzed by keeping it in boiling water for three hours with $5 \mathrm{ml}$ of $2.5 \mathrm{~N} \mathrm{HCl}$ and then cooled to room temperature. The sample was neutralized with sodium carbonate till the effervescence ceases and then transferred it to $100 \mathrm{ml}$ volumetric flask and the volume was made up to $100 \mathrm{ml} .10 \mathrm{ml}$ of this was taken in a centrifuged tube and was centrifuged for 10 minute. The supernatant was collected and 0.2 to 0.3 aliquots were taken for analysis. $12 \mathrm{ml}$ of anthrone reagent was added and heated for eight minutes in a boiling water bath.

The absorbance (OD) of the filtrate was recorded at $630 \mathrm{~nm}$. The quantity of glucose was calculated from the standard curve prepared from glucose stock solution. Amount of carbohydrate present in $100 \mathrm{mg}$ of the sample $=[(\mathrm{mg}$ sugar from $\mathrm{gram} / \mathrm{ml}$ of aliquot sample $) \times$ (Total volume of extract in $\mathrm{ml}$ of sample in $\mathrm{mg}$ ) $\times 100$

\section{Results and Discussion}

Periodical observations of Biochemical and physiogical aspects of plants were made at specific days after flowering (DAF) and significant variations were recorded before and after submergence. It was revealed from table 1 that indicated that highest Chl-a content of leaves was found in Varsadhan $(1.73 \mathrm{mg} / \mathrm{g} \mathrm{FW})$ with a reduction of $5.97 \%$ as compared to before submergence. Similarly the lowest value of the Ch1-a content was exhibited by Sarala $(1.31 \mathrm{mg} / \mathrm{g} \mathrm{FW})$ with reduction of $12.66 \%$ as compared to former one. In general chl-a content after the 
submergence was reduced irrespective of genotypes.

From table 1 it was revealed that Chl-b of leaf measured before submergence was found maximum $(0.63 \mathrm{mg} / \mathrm{g} \mathrm{FW}$ of leaf $)$ in Varsadhan and On the contrary the lowest value of the same was found in Sarala and bankoi $(0.54 \mathrm{mg} / \mathrm{g} \mathrm{FW}$ of leaf). Similar trend was observed in Chl.-b content of leaf after the submergence. The highest value was exhibited by Varsadhan $(0.59 \mathrm{mg} / \mathrm{g} \mathrm{FW}$ of leaf) with reduction of $4.8 \%$ as compared to former whereas the lowest value of the same $(0.39 \mathrm{mg} / \mathrm{g} \mathrm{FW}$ of leaf) was exhibited by Bankoi with reduction of $17.0 \%$ as compared to before submergence. The total chlorophyll content of leaf measured before and after submergence has been presented in table 1 . From the data it was revealed that total chlorophyll content of leaves before submergence was found highest in Varsadhan (2.51 mg/g FW) On the other hand, the lowest value of the same found in Sarala $(2.08 \mathrm{mg} / \mathrm{g}$ FW of leaf).After submergence highest chlorophyll content was observed in Varsadhan with a reduction of $5.97 \%$ as compared to former. Similarly the lowest total chlorophyll content was observed in Sarala (1.81 $\mathrm{mg} / \mathrm{g} \mathrm{FW}$ of leaf) with a reduction to the tune of $12.98 \%$. From the present findings it was observed that a subtle difference was noted in respect of Chl-a, Chl-b and total chlorophyll content of leaves estimated in non-stressed condition. But due to submergence there was reduction in chlorophyll contents of all the genotypes. The maximum degradation of chlorophyll content was observed in Bankoi (13.8\%) whereas minimum value of the same was showed by Varsadhan (5.9\%). Chlorophyll content of the leaves is positively correlated with 1000 seed weight and grain yield of the genotype (Table $5)$. The chlorophyll reduction is accompanied with carbohydrate reserve before the submergence in the shoot which helps in minimum shoot elongation and regulation of plant hormones like GA and ethylene. The ethylene triggered the gene expression and chlorophyllase enzyme activity which reduced the chlorophyll contents. Chlorophyll reduction was less in submergence tolerant genotypes due to reduction in ethylene production (Daset.al. 2005, Sarkar et al., 2006). The carbohydrate contents of shoot before and after submergence were presented in table 2. It was found that the shoot carbohydrate content was recorded maximum $(15.60 \%)$ in case of Varsadhan. From the data it was revealed that irrespective of varieties there was a general reduction of carbohydrate content due to submerged condition. During submergence the highest value was observed in Varsadhan (14.29 \%) with a reduction of $8.3 \%$ whereas the minimum value was found with in Sarala (11.48\%) with decrease in $20.7 \%$ as compared to non-stressed plants. Significant difference among the varieties was noted. There was a positive correlation between survival percentage and shoot carbohydrate content (Table 6).

\section{Estimation of peroxidase activity}

\begin{tabular}{|l|l|l|}
\hline \multicolumn{2}{|c|}{ REACTION MIXTURE } \\
\hline Test & Blank & Reagents \\
\cline { 1 - 2 } $2.0 \mathrm{ml}$ & $2.0 \mathrm{ml}$ & Enzyme extract \\
\cline { 2 - 2 } $2.0 \mathrm{ml}$ & $3.2 \mathrm{ml}$ & Phosphate buffer \\
Pyrogallol & $\mathrm{H}_{2} \mathrm{O}_{2}$ \\
\hline $1.0 \mathrm{ml}$ & ---- & \\
\hline $0.2 \mathrm{ml}$ & ---- & \\
\hline $5.2 \mathrm{ml}$ & $5.2 \mathrm{ml}$ & \\
\hline
\end{tabular}


Int.J.Curr.Microbiol.App.Sci (2017) 6(10): 157-165

Table.1 Chlorophyll content in rice genotypes

\begin{tabular}{|c|c|c|c|c|c|c|}
\hline \multirow{2}{*}{ Variety } & \multicolumn{2}{|c|}{ Chl.a } & \multicolumn{2}{|c|}{ Chl.b } & \multicolumn{2}{|c|}{ Total chl. } \\
\hline & BS & $\mathbf{A S}$ & BS & $\mathbf{A S}$ & BS & $\mathbf{A S}$ \\
\hline Varshadhan & 1.84 & $\begin{array}{c}1.73 \\
(-5.9 \%)\end{array}$ & 0.63 & $\begin{array}{c}0.59 \\
(-6.3 \%)\end{array}$ & 2.51 & $\begin{array}{c}2.36 \\
(-5.9 \%)\end{array}$ \\
\hline Hanseswari & 1.80 & $\begin{array}{c}1.68 \\
(-6.6 \%)\end{array}$ & 0.62 & $\begin{array}{c}0.57 \\
(-6.9 \%)\end{array}$ & 2.44 & $\begin{array}{c}2.28 \\
(-6.5 \%)\end{array}$ \\
\hline Sarala & 1.50 & $\begin{array}{c}1.31 \\
(-12.56 \%)\end{array}$ & 0.54 & $\begin{array}{c}0.47 \\
(-12.9 \%)\end{array}$ & 2.08 & $\begin{array}{c}1.81 \\
(-12.8 \%)\end{array}$ \\
\hline Jaladhan-1 & 1.70 & $\begin{array}{c}1.57 \\
(-7.6 \%)\end{array}$ & 0.59 & $\begin{array}{c}0.53 \\
(-8.6 \%)\end{array}$ & 2.32 & $\begin{array}{c}2.13 \\
(-8.1 \%)\end{array}$ \\
\hline Jaladhan-2 & 1.64 & $\begin{array}{c}1.50 \\
(-8.5 \%)\end{array}$ & 0.57 & $\begin{array}{c}0.52 \\
(-8.8 \%)\end{array}$ & 2.24 & $\begin{array}{c}2.04 \\
(-8.5 \%)\end{array}$ \\
\hline Champa & 1.75 & $\begin{array}{c}1.62 \\
(-7.4 \%)\end{array}$ & 0.61 & $\begin{array}{c}0.56 \\
(-7.5 \%)\end{array}$ & 2.39 & $\begin{array}{c}2.21 \\
(-7.4 \%)\end{array}$ \\
\hline Bankoi & 1.61 & $\begin{array}{c}1.38 \\
(-14.2 \%)\end{array}$ & 0.54 & $\begin{array}{c}0.45 \\
(-13.7 \%)\end{array}$ & 2.17 & $\begin{array}{c}1.86 \\
(-13.8 \%)\end{array}$ \\
\hline Mean & 1.69 & 1.57 & 0.59 & 0.5 & 2.31 & 2.10 \\
\hline SEM & 0.010 & 0.009 & 0.011 & 0.008 & 0.017 & 0.016 \\
\hline C.D $5 \%$ & 0.031 & 0.028 & 0.034 & 0.027 & 0.054 & 0.050 \\
\hline C.V & 1.061 & 1.033 & 3.311 & 2.929 & 1.333 & 1.364 \\
\hline
\end{tabular}

N: B: - Figure in the parentheses indicates percentage of increase or decrease over previous observation $\mathrm{BS}=$ Before Submergence

AS = After Submergence

Table.2 Carbohydrate and proline content in rice genotypes

\begin{tabular}{|c|c|c|c|}
\hline \multirow{2}{*}{ Variety } & \multicolumn{2}{|c|}{ Carbohydrate (\%) } & \multirow{2}{*}{$\begin{array}{c}\text { Proline } \\
\mathrm{mg} / \mathrm{g} \text { FW }\end{array}$} \\
\hline & BS & $\mathbf{A S}$ & \\
\hline Varshadhan & 15.60 & $\begin{array}{c}14.29 \\
(-8.3 \%)\end{array}$ & 8.73 \\
\hline Hanseswari & 15.34 & $\begin{array}{c}13.65 \\
(-11.01 \%)\end{array}$ & 9.52 \\
\hline Sarala & 14.49 & $\begin{array}{c}11.48 \\
(-20.7 \%)\end{array}$ & 11.34 \\
\hline Jaladhan-1 & 14.57 & $\begin{array}{c}12.74 \\
(-12.5 \%)\end{array}$ & 10.27 \\
\hline Jaladhan-2 & 14.78 & $\begin{array}{c}12.30 \\
(-16.7 \%)\end{array}$ & 10.24 \\
\hline Champa & 15.20 & $\begin{array}{c}13.49 \\
(-11.25 \%)\end{array}$ & 9.41 \\
\hline Bankoi & 15.05 & $\begin{array}{c}12.20 \\
(-18.9 \%)\end{array}$ & 13.99 \\
\hline Mean & 15.00 & 12.88 & 10.50 \\
\hline SEM & 0.138 & 0.158 & 0.152 \\
\hline C.D $5 \%$ & 0.426 & 1.486 & 1.470 \\
\hline C.V & 1.599 & 2.125 & 2.520 \\
\hline
\end{tabular}

$\mathrm{N}$ : B: -Figure in the parentheses indicates percentage of increase or decrease over previous observation 
Table.3 Synthesis of enzyme peroxidase and super oxide dismutase of rice genotypes

\begin{tabular}{|c|c|c|c|c|}
\hline \multirow{2}{*}{ Variety } & \multicolumn{2}{|c|}{ Peroxidase O.D/g FW } & \multicolumn{2}{|c|}{ SOD Units/g FW } \\
\hline & $\mathrm{BS}$ & AS & $\mathrm{BS}$ & $\mathrm{AS}$ \\
\hline Varshadhan & 47.14 & $\begin{array}{c}12.73 \\
(-72.3 \%) \\
\end{array}$ & 168.70 & $\begin{array}{c}69.23 \\
(-58.9 \%) \\
\end{array}$ \\
\hline Hanseswari & 47.08 & $\begin{array}{c}12.80 \\
(-71.9 \%) \\
\end{array}$ & 165.31 & $\begin{array}{c}66.24 \\
(-59.9 \%) \\
\end{array}$ \\
\hline Sarala & 45.59 & $\begin{array}{c}10.25 \\
(-78.2 \%)\end{array}$ & 160.08 & $\begin{array}{c}58.38 \\
(-64.4 \%)\end{array}$ \\
\hline Jaladhan-1 & 46.47 & $\begin{array}{c}11.56 \\
(-75.4 \%) \\
\end{array}$ & 164.79 & $\begin{array}{c}62.51 \\
(-62.00 \%) \\
\end{array}$ \\
\hline Jaladhan-2 & 46.21 & $\begin{array}{c}11.27 \\
(-75.7 \%) \\
\end{array}$ & 163.58 & $\begin{array}{c}61.26 \\
(-62.5 \%) \\
\end{array}$ \\
\hline Champa & 46.57 & $\begin{array}{c}12.55 \\
(-72.8 \%) \\
\end{array}$ & 164.12 & $\begin{array}{c}63.23 \\
(-60.5 \%) \\
\end{array}$ \\
\hline Bankoi & 46.03 & $\begin{array}{c}11.00 \\
(-76.3 \%)\end{array}$ & 166.35 & $\begin{array}{c}62.53 \\
(-62.4 \%)\end{array}$ \\
\hline Mean & 46.44 & 11.74 & 164.70 & 63.34 \\
\hline SEM & 0.172 & 0.111 & 0.255 & 0.514 \\
\hline C.D $5 \%$ & 0.531 & 0.343 & 0.788 & 1.586 \\
\hline C.V & 0.643 & 1.646 & 0.268 & 1.408 \\
\hline
\end{tabular}

Table.4 1000 grain weight, grain yield in rice genotypes

\begin{tabular}{|c|c|c|}
\hline Variety & 1000 grain weight $(\mathrm{g})$ & grain yield $\left(\mathrm{q} \mathrm{ha}^{-1}\right)$ \\
\hline Varshadhan & 24.58 & 26.70 \\
\hline Hanseswari & 21.14 & 26.03 \\
\hline Sarala & 19.46 & 19.03 \\
\hline Jaladhan-1 & 20.24 & 22.57 \\
\hline Jaladhan-2 & 20.54 & 21.80 \\
\hline Champa & 21.15 & 23.57 \\
\hline Bankoi & 23.22 & 19.83 \\
\hline Mean & 21.47 & 22.79 \\
\hline SEM & 0.105 & 0.157 \\
\hline C.D $5 \%$ & 0.325 & 0.484 \\
\hline C.V & 0.853 & 1.194 \\
\hline
\end{tabular}

Table.5 Correlation coefficient relation matrix between crop yield and yield attributing characters with chlorophyll of rice genotypes

\begin{tabular}{|c|c|c|}
\hline Parameters & Grain yield & 1000 grain weight \\
\hline Chl.a(AS) & 0.980 & 0.421 \\
\hline Chl.b(AS) & 0.954 & 0.275 \\
\hline Total chl(AS) & 0.981 & 0.400 \\
\hline
\end{tabular}

Table.6 Correlation coefficient relation matrix between biochemical parameters and with enzyme content of rice genotypes

\begin{tabular}{|c|c|c|c|c|}
\hline Parameters & Yield & Proline & Carbohydrate (AS) & Survival (\%) \\
\hline Yield & & -0.795 & 0.963 & 0.429 \\
\hline Peroxidase(AS) & 0.951 & -0.714 & 0.971 & 0.335 \\
\hline SOD(AS) & 0.915 & -0.529 & 0.940 & 0.694 \\
\hline 1000 seed weight & 0.461 & 0.005 & 0.595 & 0.829 \\
\hline
\end{tabular}


Proline content in leaves had been presented in table 2 revealed that accumulation of proline content was lowest in $(8.43 \mathrm{mg} / \mathrm{g} \mathrm{FW})$ in case of Varsadhan. On the other hand, highest proline accumulation was found in Bankoi (13.99 mg/g FW). Significant difference was recorded in respect of proline accumulation. A negative correlation was seen between the survival percentage and proline accumulation. In the present investigation, proline content estimated after submergence indicated that Varsadhan had minimum $(8.73 \mathrm{mg} / \mathrm{g})$ proline accumulation than the susceptible variety Bankoi (13.99 $\mathrm{mg} / \mathrm{g}$ ). Puckridge et al., (2008) inferred that accumulation of proline is maximum in susceptible variety under submerged condition. So proline accumulation is considered as an indicator of submergence injury where the concentration of proline builds up under stress due to hydrolysis of proteins. High carbohydrate status during submergence is related to submergence tolerance of rice crops (Yamada et al., 1955; Pal and Mitra, 1985). In the present search it was evident that higher levels of initial carbohydrate act as buffer stock and its continued slow availability is critical for the survival and growth of rice under submergence stress. The metabolic energy required by the plant during submergence is primarily supplied from stored carbohydrate present in the tissue in non-stressed condition. The present findings indicated that irrespective of genotypes there was reduction in carbohydrate content of shoot after submergence. It is obviously due to the depletion of photosynthetic rate under submerged condition attributed to reduction in leaf area and chlorophyll fluorescence and low stomatal conductance and inter cellular $\mathrm{CO}_{2}$ concentration as well. Moreover, submergence also limits the carboxylation by low/intermediate intercellular $\mathrm{CO}_{2}$ concentrations which suppress the RUBISCO activity, vis-a-vis enhancing the oxygenation process (Buchanan et al., 2004).Under submerged conditions when the leaves, stem and roots are completely submerged the rate of depletion of carbohydrate is very slow in tolerant genotypes than the susceptible genotypes. Drastic reduction in $\mathrm{CHO}$ leads to high rate of anaerobic fermentation and production of ethanol at toxic level (Setter et $a l ., 1988)$. The ability of rice coleoptiles to grow under strict anoxia during submergence was related to induction of $\alpha$-amylase causing break down of starch reserves (Perata et al., 1992). Correlation study indicated that survival of rice genotypes was positively correlated with the level of carbohydrate present in the culm and leaf before submergence, (Chatrurvedi et al., 1996) which strongly the present findings (Table 6). The activities of the enzyme peroxidase did not vary widely as per the C.V value (Table $3)$. However, the maximum activity was recorded in Varsadhan (47.14O.D $\mathrm{g}^{-1} \mathrm{FW}$ ) while the lowest value of the same was recorded in Sarala (46.64 units/ g FW). Peroxides activity recorded after submergence indicated that the activity was maximum (12.73 units/ per g FW) in Varsadhan whereas, the minimum value of the same was showed by Sarala (10.71 units/g FW). Hanseswari exhibited minimum reduction in percentage of the enzyme activity (71.9 \%) whereas maximum reduction was showed by Sarala $(78.2 \%)$. Values indicated that peroxidase activity is significantly correlated with survival of the genotypes under submerged condition. The SOD activity was estimated of all the genotypes before and after the submergence. The data reflected in table 3 indicated that the activity of the SOD enzyme estimated before the submergence was highest in Varsadhan (168.70units' $\mathrm{g}^{-1} \mathrm{FW}$ ) but as per the C.V value that there was no greater variation with regards to enzyme activity among the genotypes. The lowest value of the same was exhibited by Sarala (168.08units'g$\left.{ }^{1} \mathrm{FW}\right)$. After the submergence the SOD activities reduced in all the genotypes. 
Highest SOD was recorded from Varsadhan (69.23units' $\mathrm{g}^{-1} \mathrm{FW}$ ) with a reduction of $58.9 \%$ as compared to former observation. Similary, Sarala showed lowest SOD activity after submergence (58.38units' ${ }^{-1} \mathrm{FW}$ ) with a reduction of 64.4 percentages. The SOD activity is highly correlated with tolerant capacity of the genotype under submerged condition. The greater activities of PER under submerged condition in tolerant genotype was possible due to higher absorption of $\mathrm{O}_{2}$ from the surrounding water. The tolerant genotype had higher root activity, hence could transport more $\mathrm{O}_{2}$ through the shoot to the roots under complete submergence (Sarkar\&Bera1997). The present study is in consonance with the findings of Monk et al., (1987). According to Puckridge et al., (2008) the activities of these enzymes were higher only in the tolerant genotypes in comparison to susceptible genotypes which support the present study. Similarly the activity of SOD increased on transfer from submerged to air adapted conditions. Ushimaru et al., (1992) reported that antioxidative enzymes were co-regulated in such a way that they showed higher activities at higher $\mathrm{O}_{2}$ tension. It appeared that the activities of oxygen detoxification enzymes in previously submerged plants were restored to some extent in tolerant genotypes. Data presented in table 4 indicated that under submerged condition highest test weight was exhibited by Varsadhan $(24.58 \mathrm{~g})$ whereas the lowest value was showed by Sarala (19.46 g). Under submerged condition significant difference exhibited in both replication and genotypes. The grain yield of different genotypes tested under submerged condition was presented in table 4. Highest yield was obtained from Varsadhan (26.70 q/ha) followed by Hanseswari (26.03 q/ha) whereas lowest grain yield was obtained from Sarala (19.03 q/ha) and the percentage of reduction in yield was nearly $28.7 \%$ in Sarala as compared to Varsadhan. Significant difference in respect to yield was found among the genotypes. Comparison of grain yield between the genotypes revealed that there was wide variation in grain yield among the varieties ranging from $19.03 \mathrm{q} \mathrm{ha}^{-1}$ in Sarala to $26.70 \mathrm{q} \mathrm{ha}^{-1}$ in Varsadhan under submerged condition.

Yield components that influences grain yield of a genotype under submergence stress are 1000 grain weight, number of panicles per unit land. Chen and Wang (2008) informed that there is a greater ability of sink tissues to store sugar. So the number of panicles per hill, effective tillers per hill and 1000 grain weight are regarded as the selection criteria for adequate production of grain yield under submergence. Due to translocation of carbohydrates from leaf and stem to the sink after regeneration and also accompanied by more dry mass production after submergence the grain yield increased in tolerant genotypes (Islam et al., 2010).

\section{References}

Blokhina, O., Virolainen E., Fagerstedt, K.V. 2003. Antioxidants, oxidative damage and oxygen deprivation stress: a review. Annals of Botany; 91:179-94.

Buchanan, B.B., Gruissem, W., Jones, R.L. 2004.Flooding and oxygen deficit. In: Biochemistry and Molecular Biology of Plants. New Delhi: International Pvt. Ltd.: 1177-1179.

Chaturvedi, G.S., Ram, P.C., and Singh, A.K. 1996. Carbohydrate status of the rainfed lowland rice in relation to submergence, drought and shade tolerance. In: Physiology of Stress Tolerance in Rice, Proceeding of the International Conference on Stress Physiology of Rice, $28^{\text {th }} \quad$ feb- $5^{\text {th }} \quad$ march 1994,lucknow,UP,India.Narendra Deva University of Agriculture and Technology and International Rice Research Institute:Pp-103-135 
Chen, H.J., and Wang, S.J. 2008. Molecular regulation of sink source transition in rice leaf sheath during heading period. Acta Physiol Plant, 30: 639-649.

Ella, E.S., and Kawano, N. 2003. Blocking ethylene perception enhances flooding tolerance in rice seedlings. Funct. Plantbiol., 30: 813-819.

Islam, M.S., and Peng, S. 2010.Comparative study on yield and yield attributes of hybrids, and NPT rice genotypes in a tropical irrigated ecosystem, Bangladesh. J. Agril. Res, 35(2): 343353

Monk, L.S., and Fagerstedt, K.V. 1987.Super oxide dismutase as an anaerobic polypeptide. A key factor in recovery from oxygen deprivation in iris pseuducorus .Plant Physiol, 85: 10161020.

Panda, D., Sharma, S.G., Sarkar, R.K. 2008. Cholorophyll fluorescence parameters, $\mathrm{CO}_{2}$ photosynthetic rate and regeneration capacity as a result of complete submergence and reemergence in rice (Oryza sativa L.) Aqua Bot, 88:127-3.

Perata, P., Pozueta-Romero, J., Akazawa, T., Yamaguchi, J. 1992. Effect of anoxia on starch breakdown in rice and wheat seeds. Planta, 188: 611-618.

Puckridge, D.W., and Senadhira, D. (Eds). 1995. Breeding flood-prone rice. International Rice Research Institute, Manila.

Sarkar, R.K., 1997/98. Saccharide content and growth parameter in relation with flooding tolerance in rice. Biologia Plantarum, 40(4): 397-602.

Sarkar, R.K., and Reddy. 2006. Physiological traits on submergence tolerance rice and implication for crop improvement, Current science, 91 (7): 892-905.

Setter, 1997. Physiology and genetics of submergence tolerance in rice. Ann. Bot. 79(Suppl.A), 67-77.

Ushimaru, T.M., and Shibasaka. 1992. Development of $\mathrm{O}_{2}^{-}$detoxification system during air adaptation of submerged rice seedlings. Plant Cell Physiol, 33: 1065-1071.

Yamada, N., 1955. Physiological basis of resistance of rice plant against overhead flooding. Bulletin of the National Institute of Agricultural Sciences, Series D. Plant Physiology, Genetics and Crops in General, 8:1-112.

\section{How to cite this article:}

Soumya Mishra, Manoranjan Kar, S.P. Monalisa and Alaka Sahu. 2017. Biochemical Performance of Rice (Oryza sativa) Genotypes under Submergence Stress in Odisha, India. Int.J.Curr.Microbiol.App.Sci. 6(10): 157-165. doi: https://doi.org/10.20546/ijcmas.2017.610.020 